\title{
The Changing Structure of Retail Industry: Case Studies on Competitive Advantage of Small Companies in Croatia
}

\author{
Blaženka Knežević, Dora Naletina, Mate Damić
}

\begin{abstract}
A B S T R A C T
Objective: There are two key trends in retail industry since 1990s till nowadays: rapid internationalization and intensive retail concentration. In such a dynamic environment, small companies are striving to preserve their markets and to maintain their business activity. The objectives of the paper are twofold: (1) to explain trends of retail internationalization and concentration and (2) to highlight the possibilities for improving the competitive ability of small retailers.

Research Design \& Methods: The paper is based on analysis of secondary data available in research papers, studies and official statistics. Firstly, the consequences of retail internationalization and concentration are described. Then, the literature on competitive advantage creation is systemized. In addition, the case study method is used to illustrate successful strategies of competitive advantage creation.
\end{abstract}

Findings: In a changed retail market, small retailers seek the way to improve their competitiveness. As suitable competitiveness strategies, authors describe: (1) retail alliances and ( 2 ) differentiation by assortment.

Implications \& Recommendations: The key trends and their impact on small companies in retail industry are scrutinized. Recommendations to small retailers how to adjust to new market conditions, together with some practical examples, are given.

Contribution \& Value Added: The paper gives an insight into dynamics of changes in retail structure. Retail alliances and differentiation by assortment are described as two key streams of competitiveness improvement suitable for small retailers.

\begin{tabular}{llll}
\hline Article type: & $\begin{array}{l}\text { research paper } \\
\text { Keywords: }\end{array}$ & $\begin{array}{l}\text { retail internationalization; market structure; competitiveness; small } \\
\text { retailers }\end{array}$ \\
JEL codes: & L81, F18, D40 & & \\
\hline Received: 16 February 2016 & Revised: 19 May 2016 & Accepted: 10 June 2016 \\
\hline
\end{tabular}

Suggested citation:

Knežević, B., Naletina, D., \& Damić, M. (2016). The Changing Structure of Retail Industry: Case Studies on Competitive Advantage of Small Companies in Croatia. Entrepreneurial Business and Economics Review, 4(4), 171-187, DOI: http://dx.doi.org/10.15678/EBER.2016.040411 


\section{INTRODUCTION}

In their definition of retailing, Kent and $\operatorname{Omar}(2003$, p. 8) emphasize that retail industry consists of business activities relating to selling goods and services to final consumers. There are numerous forms, formats and organizational set-ups observed in retailing industry from a factory outlet and outdoor market sales, via convenience stores, supermarkets, chain stores and hypermarkets to the vending machines and electronic or mobile (virtual) retailing, including multichannel retailing as well.

Gilbert (2003, p. 2) pointed out that since 1960s retailing has become an important business activity in national economies that has an increasingly greater impact on the society due to its increasing role in employment and GDP creation.

In the EU retail industry is an important source of employment and influential factor of GDP creation. In addition, Knežević, Renko and Knego (2011) point out that almost a fifth of all companies registered in the EU operate in retail industry.

Tjordman (1995), Alexander (1996) and Dawson (2001; 2006) in their studies emphasize several trends that are influencing the overall retail industry and other industries as well. There are two dominant trends that influence the dynamics and structure of retail markets. First is internationalization, and the second is concentration of retail markets. Both trends have a detrimental influence on the position of small retailers.

In this paper, based on secondary data, we are going to explain both mentioned trends and their impact on small retailers. Then we will address possibilities of improvement of their competitive position. And, finally, we will describe good practices where application of the theory on competitive positioning brought small retailers to positive business results. For this purposes, the case study method is going to be applied on small, but successful, retailers' practices in Croatia.

\section{LITERATURE REVIEW}

\section{Sources of Competitive Advantage}

The key element of each firm is the pursuit of competitive advantage, especially today when firms are faced with increasing global competition and decreased growth (Vrdoljak Raguz, Jelenc \& Podrug, 2013). Tipurić (1999) points out that the competitiveness is a function of at least two groups of variables: favorable local, national and industrial conditions in which firms originate and develop, and effort to achieve results better than the competition. What is more, Wach (2014b) concludes that the firm-level international competitiveness is a very important research topic in business studies because even an internationalized local firm can compete with foreign or global competitors.

Competitive advantage exists if the following conditions are accomplished (Tipurić, 1999):

1. Customers are firstly noticing a constant difference in the important characteristics of a product/service and product/service competition.

2. The difference between the important features of the firm's product/service and product/service competition is a direct consequence of the gap firm's capabilities and its rivals. 
3. The difference between the important characteristics of the firms' product/service and products/services of competitors and skills gap between the firm and its competitors can be expected in the future.

Competitiveness of a firm in the world market is bound with its ability to respond to immediate changes of the market and to hold out the position of the enterprise in it. The idea of the competitive advantage starts from creation and distribution of value. A firm has achieved competitive advantage when its influence predetermines economic changes in the market (Lazauskas, Bureika, Valiūnas, Pečeliūnas, Matijošius \& Nagurnas, 2012).

In the last few decades in the literature of strategic management we differ industrial organization economics and resource based view (Kamasak, 2013). While the industrial organization economics theory states that performance variation of firms should be attributed to the structural characteristics of industries in which they operate, resource theory states that performance differences among firms are in relation with their internal resources.

Resource-based view (RBV) of the firm has been successfully used to explain longrun differences in firm performance that cannot be attributed to industry or economic conditions. RBV defines that firms are heterogeneous and that idiosyncratic, immobile, inimitable and intangible bundle of resources gives the firm an opportunity for competitive advantage (Habbershon \& Williams, 1999). Firms' strategy and success is based on its resource profile (Coates, 2002). Resources that are forming the base of an existing firm's competitive advantage are rarely easy to identify from the outside, and even if identified, they are difficult to replicate (Lockett \& Thompson, 2001). There are three reasons for imperfect imitability (Barney, 1991):

1. unique historical conditions,

2. casual ambiguity,

3. complex social phenomena.

Barney (1991) defines that firms obtain sustained competitive advantages by implementing strategies that exploit their internal strengths, through responding to environmental opportunities, while neutralizing external threats and avoiding internal weakness. A firm has achieved competitive advantage when it implements a value creating strategy not simultaneously being implemented by any other competitor (Barney, 2001). When competitive advantage can last for a longer period, then it is considered sustained competitive advantage. If firm's resources are valuable, rare, and imperfectly imitable and there are no strategically equivalent substitutes for them, then they hold potential for achieving sustained competitive advantage (Barney, 2001).

Competitive advantage is achieved through a combination of unique resources and capabilities that allow firms to establish nearly monopoly positions in their markets (Hamel \& Prahalad, 1994). Competitive advantage is achieved through being ahead of your competition on price/cost, quality, delivery, product innovation and time to market dimensions (Li, Ragu-Nathan, Ragu-Nathan \& Rao, 2006). With growing global competition it is difficult for companies to differentiate themselves solely on the traditional aspects of product and price. Therefore companies are forced to search for innovative ways to do business and adding value to their products (Pan \& Nagi, 2009).

The central question in competitive strategy is the relative position of the firm within the industry. Positioning determines whether the firm's profitability is above or below 
the industry average. Therefore, a firm that is well positioned can earn higher rates of return, even if the industrial structure is unfavorable (Porter, 2008). Firms must choose a strategy in order to create a unique and defendable position in the industry. Porter (2008) distinguishes two basic types of competitive advantage a firm can have: low cost or differentiation. The two basic types of competitive advantage combined with the scope of activities for which a firm seeks to achieve them, lead to three generic strategies for achieving above average performance in the industry: cost leadership, differentiation and focus (Porter, 1985). In addition to Porter, Miles, Snow, Meyer and Coleman (1978) identified three types of strategic direction that may be effective for a small business, referred to by the authors as the defender, the prospector, and the analyser. The defender-type involves the developing of a narrow product/market niche and the erection of barriers to protect it. Unlike the defender, the prospector is constantly scanning the environment for new opportunities, be their new products, services or markets. Finally, the analyser is a combination of the defender and prospector in that it simultaneously defends its niche while scanning for new opportunities.

While the strategy of cost leadership and differentiation refer to finding competitive advantage in a wide range of industrial segments, the focus strategy is based on a competitive advantage within a narrow industry segment (Porter, 2008).

If a firm wants pursue cost leadership, it must find and exploit all sources of cost advantage. Low prices cannot be sustained unless a firm maximizes its operational efficiency. Firm has to perform similar activities better than rivals and one way of doing so is to pursue a rigorous and relentless policy of cost cutting. The opening up of Eastern European markets and the integration process for Balkan countries has brought radical changes in service industry. In such a dynamic market in service sector, the low cost models in retail are changing from year to year due to changes in costs (rise and fall of oil price), regulatory laws from the EU to domestic countries and increase in competition (Rexhepi \& Stringa, 2010). Murray (1988) stated that the client demand for products and services need to be price sensitive. The high cost of investment will act as barrier of entry and it will prevent small companies to follow cost leadership strategy (Wright, 1987). In the service sector, the low cost advantages could come from new process innovations, better learning curve, new service design, less time, less costs and fully reengineering activities based on economics of scale (Allen \& Helms, 2004).

Rexhepi and Stringa (2010) defines that firms that follow cost leadership strategy in service sector should analyse the environment, target mass market, target price sensitive clients, then use control and coordination tools amongst leadership and middle managers combined with new information technology facilities to standardize services and then gradually expand.

Based on the above analysed theoretical concepts from the literature, we are going to discuss which strategies turned out to be successful for small retailers in Croatia, as Wach (2014a, pp. 42-43) concludes that strategies and strategic thinking is very important not only for big players, but also for small business.

\section{MATERIAL AND METHODS}

The analytical part of this study is divided into two parts. Firstly, we will explore the basic trends of the retail industry in Europe by using the quantitative approach based on sec- 
ondary data. Secondly, we will identify strategies used by small retailers in Croatia by using the quantitative approach based on the case study method. Therefore, the objectives of the paper are twofold:

1. to explain trends of retail internationalization and concentration,

2. to highlight the possibilities for improving the competitive ability of small retailers.

\section{Industry Analysis}

As mentioned earlier, there are two rapid trends in contemporary retailing. One is retail internationalization and another is retail concentration. Those two trends bring many issues in front of small retailers who are trying to survive and to success in the market. In this paper we will give some definitions and data on those trends and we will explain key challenges for small retailers in given market conditions.

We will use the secondary data. The first source of data will be the websites of the selected retailers, where we will collect the info on their revenue, number of stores as well as mission and vision of the company. The other source of data will be direct observation in the retailers' stores, their product mix and how they are in line with their company's mission and vision.

\section{Case Study}

In the quest for recommendation to small retailers, in this part of the paper we will analyse the sources of competitive advantage. Furthermore we will discuss and explain two basic strategies of achieving competitive advantage successfully implemented in operation of small retailers in Croatia. The analysis will be conducted through case study research method. The case study research method is an empirical inquiry that investigates a contemporary phenomenon in it is real-life context; when the boundaries between phenomenon and context are not clearly evident; and in which multiple sources of evidence are used (Yin, 2013).

The advantage of the case study method is the understanding of a complex issue or object through detailed contextual analysis of a limited number of events or conditions and their relationships. The critics of the method regard the small number of cases as a problem when establishing a generality of findings, while some regard it useful only as an exploratory tool. On the other hand, a key strength of the case study method is the usage of multiple sources and techniques in the data gathering process. Researchers from many disciplines use the case study method to build upon theory, to produce new theory, to dispute or challenge theory, to explain a situation, to provide a basis to apply solutions to situations, to explore, or to describe an object or phenomenon. The advantages of the case study method are its applicability to real-life, contemporary, human situations and its public accessibility through written reports (Soy, 1997). For this case study evidence will be taken from the websites of small retailers and small retailers' associations and through direct observation in the small retailers stores. 


\section{RESULTS AND DISCUSSION}

\section{Changes in Retail Industry and their Impact on Small Retailers}

\section{Retail Internationalization}

Retail internationalization is a process that can be observed in two dimensions (Knežević \& Szarucki, 2012): (1) internationalization of retail activities such as sourcing and logistics, and (2) internationalization of retail formats or outlets in order to approach customers at non-domestic markets.

Despite the long history or retail internationalization in sourcing and logistics, since relatively recent times the European retail sector has seen substantial expansion of international operations towards consumers at foreign markets. The rapid increase in international activity of European retailers and the expansion in European of nonEuropean retailers is one of several structural changes that have taken place since the late 1980s. In this period large firms have grown at a substantially faster rate than the sector as a whole (for more details refer to Knežević, Delić \& Knego, 2014).

Knežević, Delić and Knego (2014) analyse data on Top 250 European retailers and discuss the present situation and trends at selected Central Eastern European markets. Upon given analysis, they claim that till 2000 at Visegrad markets (Poland, Czech Republic, Slovakia and Hungary) there were more than 10 large foreign retailers present per each country, while in Croatia the number of 10 large foreign retailers is exceeded with the delay of 5 years. In addition, they found that the number of large foreign retailers at given markets has grown since 2006 (Figure 1).

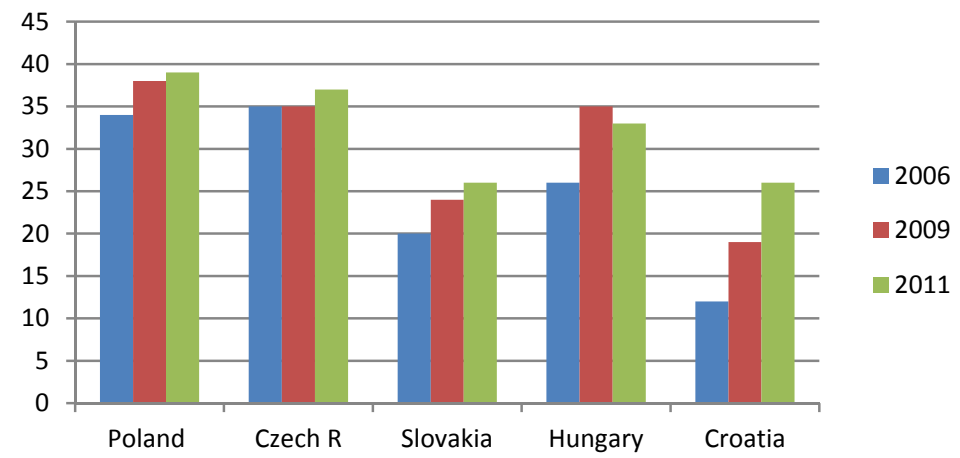

Figure 1. Total number of Top 250 global retailers present at selected Central and Eastern European countries

Source: adapted according to data at (Knežević, Delić \& Knego, 2014, p. 119).

\section{Retail Concentration}

Concentration takes a place if one or a couple of leading companies grow above average growth rates within the industry. As Dawson (2006) points, leading retailers in the EU are growing above average comparing to other market players in this industry. According to the analysis of Knežević, Renko and Knego (2011), in the newest EU members retail concentration is one of key market trends taking a place in last two decades. 
Knežević, Knego and Delić (2014) explain that concentration can be the outcome of the (a) rapid organic growth of one or several companies in the given market, or (b) mergers and acquisition taking place in a given market. Throughout the process of concentration one or several companies acquire larger and larger market share. This way they are getting better negotiation position towards suppliers and customers, better market position in comparison to competitors, their productivity per employee and per outlet grows, they have increased possibility to implement innovations and new technologies etc.

Concentration of a certain market can be measured. In EU literature, usually concentration $\mathrm{CRn}$ ratio is used to highlight how large market share is held by a certain number of companies $(n)$. For instance CR5 concentration ratio indicates the market share held by the five largest companies at the market.

Several studies show that larger and larger proportion of the retail market is controlled by a small number of companies. For instance, Data given by the European Commission (2014, pp. 51-52) show that from 2000 till 2011 concentration ratios of EU grocery market grew significantly (Figure 2). Nonetheless, EU countries differ in the level of concentration of retailing market; the trend of the concentration growth is obvious in all countries with no exception (European Commission 2014, p. 50).

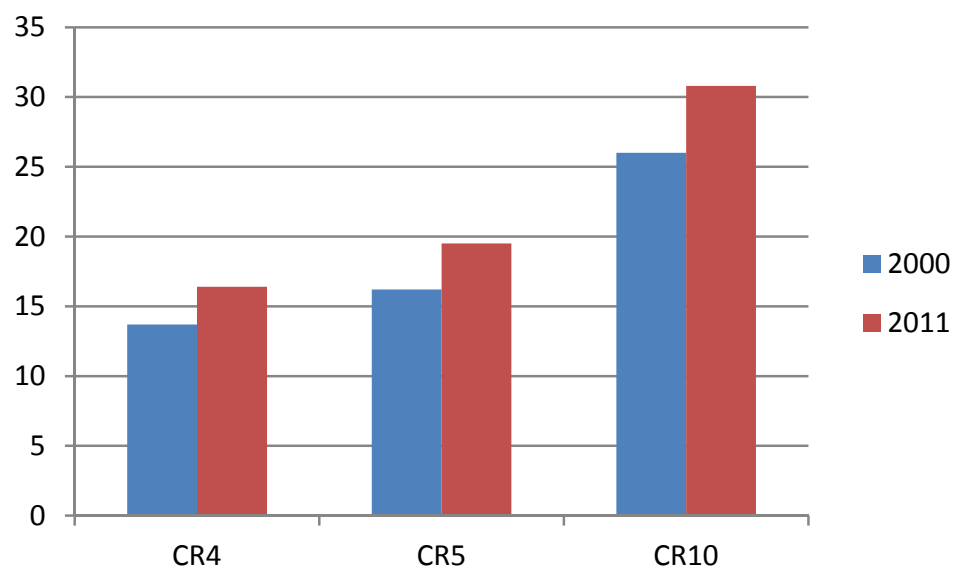

Figure 2. EU grocery retailing concentration ratios - comparison year: 2000 and 2011 Source: own calculation according to data available in (European Commission, 2014, pp. 51-52).

In Croatia, one of the newest members of the EU, the trend of retail concentration is expressed even more. Figure 3 shows concentration ratios for Croatian grocery retail market.

Not only large retailers are taking more and more retail market, but also, there is a change in the structure of retail formats. Smaller formats such as convenience stores are losing market proportion comparing to supermarkets and hypermarkets. This trend is observed around the EU (for more details refer to European Commission, 2014). For an illustration in Figure 4 we show data for Croatia grocery retail comparing years 2006 and 2012. 


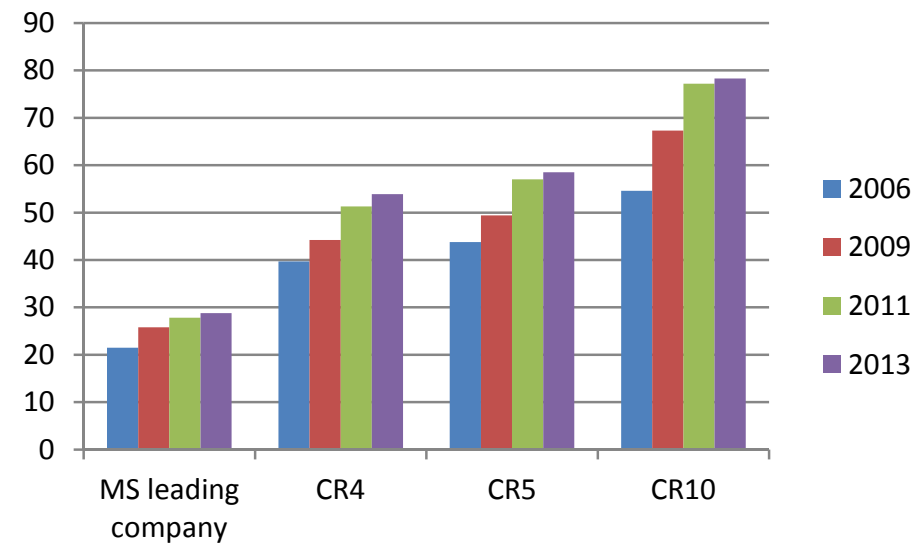

Figure 3. Grocery market shares in Croatia from 2006 to 2013

Source: adapted from (Knežević, Knego \& Delić, 2014, p. 42).

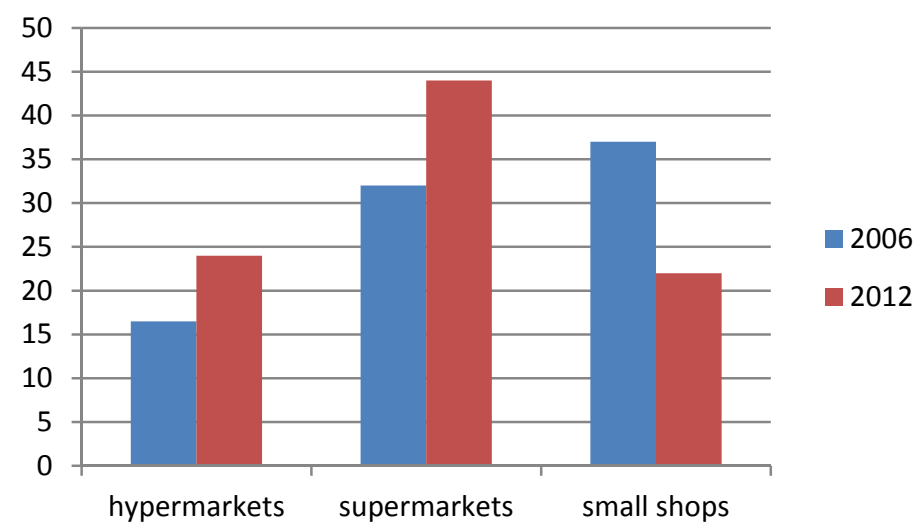

Figure 4. Market shares of grocery retail formats in Croatia (\%) Source: adapted from (Knežević, Knego \& Delić, 2014, p. 45).

\section{Key Challenges for Small Retailers}

In the previously described market conditions where international retailers control larger and larger proportion of the market and where leading companies are taking larger and larger market shares, the average size of companies measured by the number of employees per a company is growing respectively in all EU countries, especially in newer EU members (Knežević, Knego \& Renko, 2011). In addition, the number of small and medium retailing companies diminishes. Knežević, Knego and Renko (2011) analyse the situation in Croatia and draw a conclusion that, according to the number of enterprises classified by their size, the retail structure is becoming polarized. Namely, in Croatia out of all enterprises in retailing industry $42 \%$ are micro companies (less than 10 employees), $35 \%$ 
are large companies (more than 250 employees); there are 16\% of small companies (10 to 50 employees) and only $7 \%$ medium companies.

While overall productivity in retailing industry grows, in terms of revenues per employee for large retailers, small retailers are experiencing various issues in their operation and are forced to seek for survival strategies and policies. Knego and Knežević (2011) point to following issues faced by small retailers (Figure 5): (a) unfavorable procurement conditions, (b) lower turnover rate, (c) lower labor productivity, (d) lower gross margins and (e) higher sales prices.

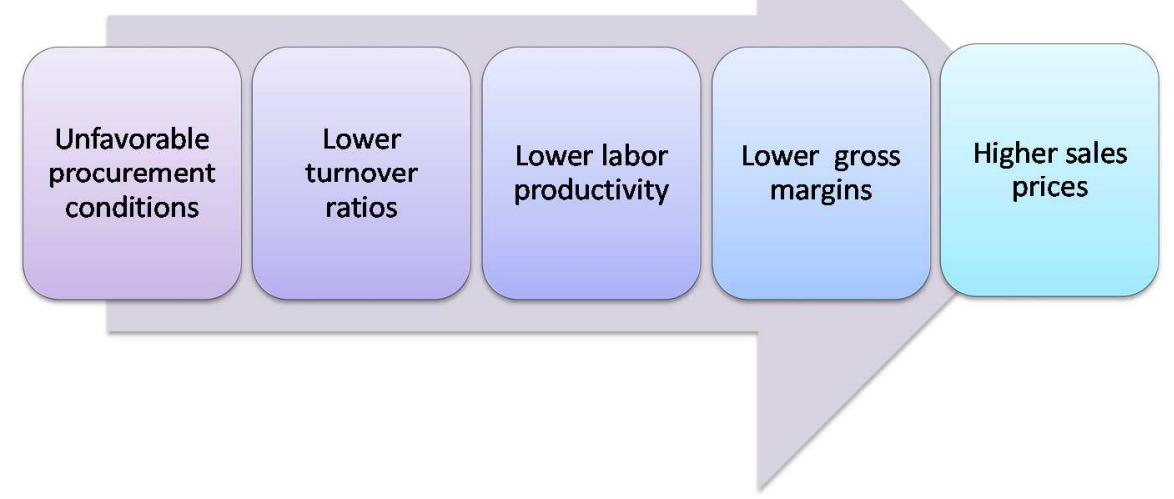

Figure 5. Problems of Small Retailers

Source: adapted from (Knego \& Knežević, 2011, p. 3).

The unfavorable procurement condition of small companies is the result of their low negotiation power because of small quantities being purchased. Therefore, comparing to the large retailers they cannot negotiate with suppliers well and the consequences are higher input prices of goods and services and higher transport and warehousing costs comparing to large retailers. In addition, their negotiating skills are lower due to the fact of lower knowledge capacities of their employees because the majority of retailers cannot afford highly educated managers and employees. Moreover, small retailers often cannot approach the producer directly because of the existing relationships and contractual arrangements within supply chains, and they are forced use intermediate companies to purchase product and services which increases input prices even more.

On the other hand, lower turnover ratio is the result of lower capacities on their position towards consumers. Usually small retailers serve to the narrow geographic location and the number of potential customers is lower in comparison to large retailers' formats. To achieve quantity discounts from their suppliers, they are motivated to buy bulk quantities and usually, due to their lack of management knowledge and skills, they do not apply methods and techniques of inventory planning and management. Knego and Knežević (2011) analysed tradesmen (organized as small crafts) and retailers as legal 
entities (retailing enterprises) and draw a conclusion that inventory turnover of tradesmen had never reached more than $60 \%$ of those in legal entities (retailing enterprises).

Lower labor productivity (measured by revenues per employee, see Knego and Knežević, 2011) is the direct output of lower revenues generated by small retailers in comparison to large companies which is the result of their limited market approach, limited knowledge and skills and limited resources available for technological improvement and innovation (in terms of processes, outlet and shop design, promotion, information technology implementation and utilization etc).

As a consequence of all above mentioned, the gross margin as the difference of revenues and cost of sold goods is significantly lower for small retailers. This forces small retailers to apply additional cost cutting policies which usually has detrimental influence on wages, shop and outlet design, lowering marketing activities, cutting the number of employees and lowering service offered, cutting investment in knowledge and skills development and information technology etc. In the longer run, such policies have damaging impact on their competition position and therefore, they should seek some other solutions for their survival. In the next chapters we will give some suggestions and examples of a different approach.

Due to higher input prices and higher operating costs, in comparison to large retailers, small retailers have higher sales prices. In Croatia, based on price study of 10 standard grocery products, in small shops owned by small retailers, on the average prices are $23,47 \%$ higher compared to the lowest available price offered by large retailer (note: own calculation based on data available in Knego \& Knežević, 2011).

\section{Retailers Associations as a Source of Competitive Advantage for Small Retailers}

As a source for gaining competitive advantage by increasing the efficiency of procurement, in developed European countries for a longer time multi-firm associations of retailers are known (sourcing alliances) with buying groups in a special subform. In addition there are newer forms with developed service in purchasing and supplier marketing at European and global level (sourcing offices).

Multi-firm associations are communities of economically independent companies formed for the purpose of cooperation in purchasing, sales, investment and financing, and usually are established as separate companies (Tietz, 1993, p. 321). In retailing industry in Germany, they emerged at the turn of the 1960s and 1970s, when the mediumsized companies joined at the national level in order to achieve better performance in the market (Liebmann \& Zentes, 2001, p. 281). Today they are not focused exclusively on the national market, but are oriented to cover a region, the continent and even global level. Buying groups, as a narrower form of sourcing associations, are associations of retailers which are formed in order to organize joint procurement of goods and services with the main goal to gain a better negotiating position among suppliers.

In the EU there are several large retailers sourcing associations, and they can be classified according to the type of goods in focus. For groceries and fast moving consumer products examples are: EMD, AMS, Rewe and Edeka; textile: Garant; furniture: Atlas, Begros and VME, building supplies: Hagebau; electronics and household appliances: Euronics (according to Dawson \& Mukoyama, 2006; Wortmann, 2002), etc.

In Croatia mentioned sourcing associations are present indirectly, through operation of their members, for example, EMD is present through Müller, Kaufland and dm- 
drogerie markt. In addition, we can observe increased association processes between small and medium retailers and good examples are NTL and Ultra Gros, Table 1 shows a brief profile and the strength of buying groups in Croatia measured by revenues, number of employees and the number of stores within the buying group.

Table 1. Buying Groups in Croatia

\begin{tabular}{|c|l|c|c|c|}
\hline $\begin{array}{c}\text { Name of the } \\
\text { group }\end{array}$ & Established & $\begin{array}{c}\text { Revenues } \\
\text { (in bil. HRK) }\end{array}$ & $\begin{array}{c}\text { Number of } \\
\text { Employees } \\
\text { Involved }\end{array}$ & $\begin{array}{c}\text { Number of } \\
\text { Stores Involved }\end{array}$ \\
\hline $\begin{array}{c}\text { NTL } \\
\text { (Narodni trgovački } \\
\text { lanac) }\end{array}$ & March 2005 & 4.4 & 6578 & 1229 \\
\cline { 2 - 5 } & $\begin{array}{l}\text { Members (8): Bakmaz, Studenac, Boso, Metss, Pemo, Trgovina Krk, } \\
\text { Trgostil Donja Stubica, Gavranović Zagreb }\end{array}$ & 947 \\
\hline \multirow{3}{*}{\begin{tabular}{l} 
Ultra gros \\
\cline { 1 - 4 }
\end{tabular}} & $\begin{array}{l}\text { End of 2001 } \\
\text { Members (21): Dinova Diona, Djelo, Duravit, Jadranka trgovina, } \\
\text { Jeruzalem, Kvarner Punat trgovine, La-vor trade, Lonia, Mlin i pekare, } \\
\text { PPK, Prehrana, Ribola, Sonik, Strahinjčica, TP Varaždin, Trgocentar, } \\
\text { Trgonom, Union, Valalta, Victa, Vrutak }\end{array}$ \\
\hline
\end{tabular}

Source: Poslovna Hrvatska (2015).

\section{Gaining Competitive Advantage through Differentiation and Focusing on a Market Niche}

The focus strategy implicit that firm selects a segment or group of segments in the focused industry (Porter, 1985). Focus strategy involves concentrating on a specific, market, group of customers, product or service. Firms pursuing a focus strategy create competitive advantage in a narrow and well-defined niche to avoid head-on collisions with large competitors (Ibrahim, 2015).

Prior research suggests that focus (niche) is by far the most effective strategy for small business. Previous research by Ibrahim and Goodwin (1986) supports this conclusion. A small firm pursuing a niche strategy creates a competitive advantage in a narrow and well-defined niche to avoid direct rivalry with large competitors. Areas of distinctive competence identified by Stoner (1987) include quality of product or service, location, know-how, uniqueness of product or service and pricing. The defender and prospectortype strategies are highly pursued by small business owners and managers. This seems to confirm some earlier studies. Small firms pursuing either defender or prospector types achieved better performance than those employing an analyser-type strategy. Rugman and Verbeke (1988) reported that prospector-type strategy is the most pursued strategic direction followed by the defender-type. The researchers concluded that Miles et al. (1978) typology is more appropriate for small business than Porter's generic-type strategies.

If a firm uses a product differentiation strategy then it seeks to be unique in its industry along some dimensions that have value for the buyers. It selects one or more attributes that buyers perceive as important (Porter, 1985). As with price, retailers are interested in offering the best, or optimal, assortment of goods and services to attract customers. Retailers can choose to differentiate their assortments by providing items unique to the market, which can increase the number of stores needed to make a price comparison on an item and, at the extreme, make price comparisons impossible 
(Stassen, Mittelstaedt \& Mittelstaedt, 1999). Product assortment can play a key role, not only in satisfying wants, but also in influencing buyer wants and preferences (Simonson, 1999). Product assortment is a very important factor in achieving differentiation and satisfying the wants of target shoppers better than the competition (Kotler, 1997).

As good and successful examples of implementation of the differentiation strategy in food retailing in Croatia we can describe the Biovega company and company "Domaće I fino" Itd. Biovega is a Croatian retail company founded in 1990. Bio Bio is a retail chain owned by Biovega specialized in selling ecological products, mostly food, beverages, cosmetics and household products. The company currently has 17 stores located in major Croatian cities, mostly in Zagreb with a yearly turnover of 14 million EUR in 2014 compared to 10.2 million in 2012 and 11.5 million in 2013 respectively.

The company's suppliers are required to have an ecological certificate that guarantees the sourcing and quality of their products as well as a good public image and experience on the Eco products market. Assortment of products in Bio Bio stores tends to be almost $100 \%$ ecological. The company also aims to offer products that are processed in the least possible manner. Assortment sustainability and responsible sourcing is another important issue. The company tends to cooperate with the Croatian eco farmers and encourage them to produce food in a manner that is responsible both for the environment and the society. Biovega also has its own eco farmstead "Zrno" as well as a vegetarian restaurant also called "Zrno". The company does not offer any meat products due to ethical reasons. In 2014 the company received an corporate social responsibility reward in the category of employee care from the Croatian Employers Association. Biovega quality control department, that controls health safety and registration of products consists of experts in regulatory affairs, controlling, certification, check-in system monitoring (for dietary supplements, foods with health claims, food with special properties and baby food), as well as professional sanitary engineer, a pharmacist and a representative of the Management Board.

Another source of the company's competitive advantage is highly specialized employees. Since Biovega was one of the companies that established the eco food retail nice in Croatia it can be said that the company's management possesses a better knowledge of the business processes than the competitors in this niche. The sale persons are required to be working professionals with experience in food sector or nutritionists. Ethical and transparent communication is also important for the company image, therefore the public relation sector employees are experts in the fields of social sciences: sociology, philosophy, linguistics, and visual design. Employees at all work processes have specialized knowledge that their workflow requires. The greatest attention is paid to education of employees in stores who undergo a program of lifelong learning and continuous education about the products from the company's portfolio and the upcoming trends to provide quality services.

In order to upgrade the quality, the company implements ISO 9001 and HACCP systems. The purpose of the introduction of ISO 9001 system is the improvement of business planning and development of quality awareness within the organization, providing an appropriate level of communication with customers and suppliers (partners) on mutual benefit, customer-orientation, reduction of losses (non-conforming goods or services), and process control. While the goal of the HACCP system is to protect the health 
of consumers in food industry and distribution, and it takes place in six areas: Space Requirements, Storage requirements, Equipment and maintenance, Staff Training, Hygiene Program, SSOP Sanitation Standard Operating Procedures, the return of goods.

Some small retailers choose even narrower niche than Biovega. For instance, 'Domaće i fino' applies even more rigorous differentiation strategy and is focusing towards even narrower market niche by assortment differentiation policy based on the presumption of consumer ethnocentrism. The mentioned company is oriented on selling "so called" domestic food manufactured strictly by the Croatian farmers. Moreover, the company is basing its market strategy on virtual sales channel as the basis for communication with consumers. Actually, 'Domaće i fino' company started as the first Croatian online domestic food shop in 2010. Today it also has a physical shop in Zagreb. The company's turnover was 30000 EUR in 2012 and 200000 EUR in 2013.

Another example that supports the theory of differentiation and focusing is 'Greencajg' as very successful highly specialized online retailer. With its assortment policy based on organic food of own brands, 'Greencajg' is targeting even narrower niche because it is oriented mainly to narrow geographic area around Zagreb city. Therefore, we can conclude that there is a space for other small retailers to develop by applying differentiation and focusing generic strategies suggested by Porter.

\section{CONCLUSIONS}

Retail internationalization and retail concentration are two key trends in the European retailing industry. Their consequence is increasingly difficult position of small retailers which do not have enough resources and knowledge to compete with large international retail chains. In such conditions small retailers, in comparison to large retailers, face various issues such as low negotiation power towards suppliers, low turnover ratios low productivity rates, low margins, and consequently higher sales prices.

According to the literature on competitive advantage creation, small retailers can seize some opportunities offered by new market conditions. In this paper we suggested that retailers associations can improve their negotiation power towards suppliers. In addition, we described the implementation of differentiation by assortment as another strategy of market survival. For both cases we privided practical examples from Croatia. Also, it should be stated that the resource based view theory deals with the problems of choosing the directions for business diversification and it can't be applied for small companies. All of these findings can be a good starting point for further research into strategies that can be applied by small retailers as an answer to new trends in the retail industry, as well as useful information for managers in the retail sector.

Nonetheless, we have to point out that this paper was mainly based on secondary data which was a limitation of the research and this topic should be further developed by in-depth analysis of other good practices and examples from retailing industry. 


\section{REFERENCES}

Alexander, N. (1996). International Retail Expansion within the EU and NAFTA. European Business Review, 95(3), 23-35.

Allen, R.S., \& Helms, M.M. (2006). Linking strategic practices and organizational performance to Porter's generic strategies. Business Process Management Journal, 12(4), 433-454.

Barney, J.B. (1991). Firm resources and sustained competitive advantage. Journal of Management, $17(1), 99-120$.

Barney, J.B. (2001). Resource-based theories of competitive advantage: A ten-year retrospective on the resource-base view. Journal of Management, 27(6), 643-650.

Coates, T.T., \& McDermott M.C. (2002). An exploratory analysis of new competencies: a resource based view perspective. Journal of Operation Management, 20(5), 435-450.

Dawson, J. (2001). Strategy and Opportunism in European Retail Internationalization. British Journal of Management, (12), 253-266.

Dawson, J. (2006). Retail Trends in Europe. In M. Kraft \& M.K. Mantrala (Eds.), Retailing in the 21st Century (pp. 41-58). Berlin: Springer.

Dawson, J., \& Mukoyama, M. (2006). The increase of international activity by retailers. In J. Dawson, R. Larke \& M. Mukoyama (Eds.), Strategic issues in International Retailing (pp. 1-30). Abingdon: Routledge.

European Commission (2014). The Economic impact of modern retail on choice and innovation in the EU food sector. Retrieved on December 8, 2015 from http://ec.europa.eu/competition/publications/KD0214955ENN.pdf

Gilbert, D. (2003). Retail Marketing Management. Glasgow: Pearson Education Limited.

Habbershon, T.G., \& Williams, M.L. (1999). A Resource-Based Framework for Assessing the Strategic Advantages of Family Firms. Family Business Review, 12(1), 1-25.

Hamel, G., \& Prahalad, C.K. (1994). Competing for the future: breakthrough strategies for seizing control of your industry and creating markets for tomorrow. Boston, MA: Harvard Business School Press.

Ibrahim, A.B. (2015). Strategy Types and Small Firms' Performance An Empirical Investigation. Journal of Small Business Strategy, 4(1), 13-22.

Ibrahim, A.B., \& Goodwin, J.R. (1986). Perceived causes of success in small business. American Journal of Small Business, 11(2), 41-50.

Kamasak, R. (2013). Resource-Based View (RBV) in all its aspects. Why some firms outperform others?. Germany: Scholar's Press.

Kent, T., \& Omar, O. (2003). Retailing. New York: Palgrave Macmillan.

Knego, N., \& Knežević, B. (2011). The Position of Small Retailers in Croatia on the Verge of Entering the European Union. In Proceedings of 8th International Conference "Economic Integration, Competition and Cooperation", 6-9 April, Opatija, University of Rijeka - Faculty of Economics. Retrieved on December 8, 2015 from http://ssrn.com/abstract=2232657

Knežević, B, \& Szarucki, M. (2013). Internationalization of Retail in Poland and Croatia. In S. Renko \& B. Knežević (Eds.), Challenges for the Trade of Central and Southeast Europe (pp. 1-18). Bingley, UK: Emerald Publishing.

Knežević, B., Delić, M., \& Knego, N. (2014). The Retail Internationalization in Visegrad Countries and Croatia. In K. Wach \& B. Knežević (Eds.), International Business from the Central European Perspective (pp. 113-128). Zagreb: University of Zagreb. 
Knežević, B., Knego, N., \& Delić, M. (2014). The Retail Concentration and Changes of the Grocery Retail Structure. InterEULawEast, 1(2), 37-51.

Knežević, B., Renko, S., \& Knego, N. (2011). Changes in Retail industry in EU. Business, Management and Education, 9(1), 34-49.

Kotler, P. (1997). Marketing Management: Analysis, Planning, Implementation, and Control. Englewood Cliffs, NJ: Prentice Hall.

Lazauskas, J., Bureika, G., Valiūnas, V., Pečeliūnas, R., Matijošius, J., \& Nagurnas, S. (2012). The research on competitiveness of road transport enterprises: Lithuanian case. Transport and Telecommunication, 13(2), 138-147.

Li, S., Ragu-Nathan, B., Ragu-Nathan, T.S., \& Rao, S. (2006). The impact of supply chain management practices on competitive advantage and organizational performance. Omega, 34(2), 107-124.

Liebmann, H-P., \& Zentes, J. (2001). Handelsmanagement. München: Verlag Franz Vahlen.

Lockett, A., Thompson, S., \& Morgenstern, U. (2009). The development of the resource-based view of the firm: A critical appraisal. International Journal of Management Reviews, 11(1), 9-28.

Miles, R.E., Snow, C.C., Meyer, A.D., \& Coleman, H.J. (1978). Organizational strategy, structure, and process. Academy of Management Review, 3(3), 546-562.

Murray, A.I. (1988). A contingency view of Porter's "generic strategies". The Academy of Management Review, 13(3), 390-400.

Pan, F., \& Nagi, R. (2009). Robust supply chain design under uncertain demand in agile manufacturing. Computers \& operations research, 37(4), 668-683.

Porter, M.E. (1985). Competitive Advantage. New York: Free Press.

Porter, M.E. (2008). Konkurentska prednost, Postizanje i održavanja vrhunskog poslovanja. Zagreb: Masmedia.

Poslovna Hrvatska (2015). Annual financial statements of the selected companies for 2014. Retrieved on December 22, 2015 from http://www.poslovna.hr

Rexhepi, P., \& Stringa, O. (2010). How Multinational Companies (MNCs) Implement Cost Strategies at airline and Retail Supermarket Industry in Albania. Retrieved on 29 January 2016 from http://www.Ise.ac.uk/europeanInstitute/research/LSEE/PDFs/PhD\%20Symposium/Papers\%20 2010/Rexhepi.pdf

Rugman, A.M., \& Verbeke, A. (1988). Does competitive strategy work for small business? Journal of Small Business \& Entrepreneurship, 5(3), 45-50.

Simonson, I. (1999). The effect of product assortment on buyer preferences. Journal of Retailing, 75(3), 347-370.

Soy, S. (1997). The case study as a research method. Retrieved on May 12, 2016 from http://elibrary.wats.edu.ng/handle/123456789/11244

Stassen, R.E., Mittelstaedt, J.D., \& Mittelstaedt, R.A. (1999). Assortment overlap: its effect on shopping patterns in a retail market when the distributions of prices and goods are known. Journal of Retailing, 75(3), 371-386.

Stoner, C.R. (1987). Distinctive competence and competitive advantage. Journal of Small Business Management, 25(2), 33.

Tietz, B. (1993). Der Handelsbetrieb. Grundlagen der Unternehmenspolitik. München: Verlag Franz Vahlen.

Tipurić, D. (1999). Konkurentska sposobnost poduzeća. Zagreb: Sinergija nakladništvo d.o.o. 
Tordjman, A. (1995). European Retailing: convergences, differences and perspectives. In P.J. McGoldrick \& G. Davies (Eds.), International Retailing (pp. 17-42). London: Pitman Publishing.

Vrdoljak Raguž, I., Jelenc, L., \& Podrug, N. (2013). Izvori konkurentske prednosti u XXI. stoljeću. Dubrovnik: Sveučilište u Dubrovniku.

Wach, K. (2014a). International Strategies of Businesses: Some Evidence from Internationalised Polish Firms (Chapter 3). In A.S. Gubik \& K. Wach (Eds.), International Entrepreneurship and Corporate Growth in Visegrad Countries (pp. 101-124). Miskolc: University of Miskolc.

Wach, K. (2014b). The Theoretical Modelling of the Firm-Level International Competitiveness in Business Studies (Chapter 5) In D. Kiendl-Wendner \& K. Wach (Eds.), International Competitiveness in Visegrad Countries: Macro and Micro Perspectives (pp. 41-56). Graz: Fachhochschule Joanneum.

Wortmann, M. (2003). Strukturwandel und Globalisierung des deutschen Einzelhandel. WZB Discussion Paper. Berlin: WZB - Wissenschaftszentrum Berlin für Sozialforschung.

Wright, P. (1987). A refinement of Porter's strategies. Strategic Management Journal, 8(1), 93-101.

Yin, R.K. (2013). Case study research: Design and methods. London: Sage Publications. 


\section{Authors}

The contribution of co-authors is equal. B. Knežević made conceptual framework, prepared the literature review, and did analysis of retail trends, D. Naletina analysed and systematized literature on competitive strategies, and M. Damić did case studies and calculations to illustrate trends and good practices.

\section{Blaženka Knežević}

Associate Professor at the Department of Trade, University of Zagreb. PhD in Economics (2008).Guest lectures in many universities in Europe such as: University of Stirling, Cracow University of Economics, Vilnius Gediminas Technical University, University of Belgrade. She has published more than 50 papers in scientific journals, chapters in books and proceedings of international scientific conferences. She is reviewer and/or member of editorial board in many peer review academic journals in field of business administration, marketing and management. Her research interests include economics of electronic commerce, information systems in retailing, procurement management and retail supply chains.

Correspondence to: Izv. prof. dr. sc. Blaženka Knežević; University of Zagreb, Faculty of Economics and Business, Department of Trade; Trg J. F. Kennedy 6, 10000 Zagreb, Croatia; e-mail: bknezevic@efzg.hr

\section{Dora Naletina}

Teaching and Research Assistant at the Department of Trade at the Faculty of Economics and Business in Zagreb. PhD in Economics (2016). She is teaching courses at undergraduate and graduate level at Faculty of Economics and Business Zagreb.

Correspondence to: Dora Naletina, PhD; University of Zagreb, Faculty of Economics and Business, Department of Trade; Trg J. F. Kennedy 6, 10000 Zagreb, Croatia; e-mail: dora.naletina@efzg.hr

\section{Mate Damić}

Teaching and Research Assistant at the Department of Trade at the Faculty of Economics and Business in Zagreb. Currently a PhD student in Economics and Business at the University of Zagreb. He is teaching courses at undergraduate and graduate level.

Correspondence to: Mate Damić, MA; University of Zagreb, Faculty of Economics and Business, Department of Trade; Trg J. F. Kennedy 6, 10000 Zagreb, Croatia; e-mail: mdamic@efzg.hr

\section{Acknowledgements and Financial Disclosure}

The article came into being within the project entitled "Innovations in Supply Chains in Conditions of Retail Internationalization" [in Croatian: "Inovacije u lancima opskrbe u uvjetima internacionalizacije maloprodaj"] financed by University of Zagreb, Croatia, conducted by Blazenka Knezevic and team in the year 2015. The research is partially supported by Croatian Science Foundation under the project UIP-2014-09-4057.

\section{Copyright and License}

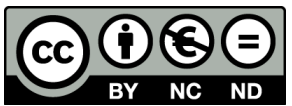

This article is published under the terms of the Creative Commons Attribution - NonCommercial - NoDerivs (CC BY-NC-ND 3.0) License http://creativecommons.org/licenses/by-nc-nd/3.0/ 
